\title{
ASSESSMENTS OF BIODIVERSITY AND HABITAT SERVICES IN CITIES - EXEMPLIFIED BY DRESDEN (GERMANY) AND LIBEREC (CZECH REPUBLIC)
}

\author{
OLAF BASTIAN ${ }^{1}$, PAVEL CUDLÍN ${ }^{2}$, VILÉM PECHANEC ${ }^{3}$, PATRYCIA BRZOSKA ${ }^{4}$, \\ LENKA ŠTĚRBOVÁ ${ }^{2}$, RENATA VČELÁKOVÁ ${ }^{2}$, JAN PURKYT ${ }^{2}$, KARSTEN GRUNEWALD $^{4}$ \\ ${ }^{1}$ Environmental Office, Capital City of Dresden, Environmental Office, P.O. Box 120020, Grunaer Straße 2, D-01001 \\ Dresden, Germany; e-mail: obastian@dresden.de \\ ${ }^{2}$ Global Change Research Institute, Czech Academy of Sciences, České Budějovice, Czech Republic \\ ${ }^{3}$ Department of Geoinformatics, Faculty of Science, Palacký University in Olomouc, Olomouc, Czech Republic \\ ${ }^{4}$ Leibniz Institute of Ecological Urban and Regional Development, Dresden, Germany
}

\begin{abstract}
Bastian O., Cudlín P., Pechanec V., Brzoska P., Štěrbová L., Včeláková R., Purkyt J., Grunewald K.: Assessments of biodiversity and habitat services in cities - exemplified by Dresden (Germany) and Liberec (Czech Republic). Ekológia (Bratislava), Vol. 39, No. 2, p. 174-189, 2020.

The choice of suitable biodiversity assessment methods for practical purposes in city planning and decision-making is still a challenging problem. Despite the availability of a wide variety of methods for almost all dimensions of diversity (mainly species and habitat diversity, including spatial aspects), few of them have entered the practical 'daily' work. In the example of in-depth examinations in German and Czech cities (e.g., Dresden and Liberec), it was found that the most frequently applied analyses are those of protected species and habitats in urban nature conservation in general, and particularly in city development planning to derive avoidance, protection and compensation measures. Preference analyses (questionnaires, structured interviews) are becoming increasingly popular. Economic calculations of habitat values and the valuation of ecosystem services are still in their infancy. We will present methods that are presently being applied or could be included in a practical methodological toolkit to analyse and valuate biodiversity in urban nature conservation, city planning and decision-making.
\end{abstract}

Key words: economic valuation, land use, preference analyses, protected species, vegetation.

\section{Introduction}

Plants, animals, and microorganisms including fungi are the basis of all ecosystems and the services they provide. Not only pristine and rural areas but also urban and peri-urban areas can host a rich biodiversity and deliver a wide range of benefits to sustain and improve human livelihood and the quality of life through ecosystem services (TEEB, 2011). Due to the permanently growing proportion of people living in cities, biodiversity is continuously gaining importance. On the one hand, the diversity of species and genetic variants is an inherent component of ecosystems; it can be a regulator of ecosystem processes but also a prerequisite 
for various ecosystem services it supports. On the other hand, biodiversity itself can be a good (Mace et al., 2012) or the result of ecosystem services (particularly the habitat service, i.e., the capacity or the service to provide suitable living spaces and living conditions for plants and animals), which can be classified as a regulating, supporting or intermediate service. In the sense of the international CICES classification of ES (Haines-Young, Potschin, 2018), habitat service(s) belong to the 'group' of 'Lifecycle maintenance, habitat and gene pool protection', which is part of the division of 'Maintenance of physical, chemical, biological conditions'.

Cities can be important sites of local and regional biodiversity. Within their boundaries, the richness of land cover types and intensities of land use create a wide array of different habitats and microhabitats, and highly varied habitat mosaic configurations. Biodiversity in cities is adapted to human settlements in different ways. There are species that occur predominantly or exclusively in cities or species that occur both in urban areas and in the wider landscape, but also species that avoid urban spaces and habitats (Werner, Zahner, 2009).

Ecological characteristics of cities relevant for urban biodiversity include the existence of (e.g., Werner, 2016; Bastian, Xiao, 2018):

- dry and heat islands,

- small structures, small-scale spatial patterns of site conditions and land use,

- wilderness on fallow land,

- frequently disturbed habitats,

- a high share of thermophilic and non-native species,

- $\quad$ refuge and substitute habitats, stepping stones.

It is very important to assess the present state of biodiversity in cities in order to

draw the appropriate conclusions for planning and management, on the one hand because of the (intrinsic) value of biodiversity underpinned by legal obligations, on the other hand as the sustainable supply of many ecosystem goods and services largely depends on maintaining biodiversity at a favourable conservation status.

More or less all spheres of biodiversity (UNEP, 1992) are relevant in city planning and management, especially:

- $\quad$ species diversity (number of species),

- diversity of ecosystems, biocenoses, habitats, and landscapes,

- for particular questions, also genetical diversity (within-species diversity), for example, varieties of fruits.

The choice of suitable biodiversity and habitat service assessment methods for practical purposes in city planning and decision-making is still a challenging problem. Data availability, personnel and monetary resources are crucial as well as the specific tasks to be performed, for example, nature conservation (protection of species, habitats, areas), compensation and replacement measures, land use and landscape planning. A wide variety of methods and approaches have been described in the literature or used in case studies (User's manual for CBI, 2012; Grunewald, Bastian, 2017). But few methods are actually applied under practical conditions in city administrations.

The aim of the study was to find which role methods to analyse and valuate biodiversity in its different dimensions play in urban nature conservation, city planning and decision-making. In this paper, we present a bundle of methods that are presently being applied or could 
be included in a practical methodological toolkit without major difficulties, particularly in cities. We refer to data availability, feasibility to work with these methods, and expressiveness of the results. We show advantages and problems of methods, and we discuss necessities, opportunities and limitations for broadening the toolkit.

The investigation was performed in the framework of the EU project BIDELIN (The value of ecosystem services, biodiversity and blue-green infrastructures in cities, exemplified by Dresden, Liberec and Děčín) (2017-2019), supported by the European Union, the Free State of Saxony (Germany) and the Czech Republic (Project No. 100282320) (IÖR, 2019). Therefore, we focus on experiences, data and applications from Germany and the Czech Republic, particularly from the cities of Dresden and Liberec.

Dresden is the capital city of the German federal state of Saxony, which borders on the Czech Republic and Poland. The city lies in a marked widening of the Elbe river valley. Its total population is c. 563,000 inhabitants. The territory stretches over several physical landscapes: a hilly loess region, and foothills of lower mountain ranges. The Elbe river with its broad floodplain mostly covered by semi-natural meadows crosses the entire city from southeast to northwest. Though surface sealing and intensive land use have changed the natural conditions drastically, the inner city is greened by parks and avenues but also by many small habitats of partly rare and threatened plants and animals.

Liberec is one of the biggest and most important cities of Northern Bohemia. The city lies at the Lužická Nisa at the foot of the Ještědský hřbet, covered partially by the Nature Park Ještěd and the Protected National Area Jizerské hory mountains. Commercial spruce forests, some beech forests, and semi-natural meadows occur on its cadastral territory. However, in the city centre, there are only a few parks and other urban greenery. Its population is 102,000 inhabitants.

\section{Methods}

In order to identify methods that are presently being applied or could be included in a practical methodological toolkit to analyse and valuate biodiversity in urban nature conservation, city planning and decision-making, the following working steps were involved in the investigation:

- literature analysis referring to biodiversity assessment methods in cities,

- $\quad$ assessment of the practical experiences in city administration and planning, particularly in the cities of Dresden and Liberec,

- $\quad$ evaluation of the suitability of existing methods to assess biodiversity and ecosystem services in cities,

- application of these methods in the framework of the BIDELIN project to assess ecosystem services in both cities included in the study,

- $\quad$ identification of research gaps, challenges, and limitations.

We classified the methods according to their complexity, from the direct counting and mapping of species and ecosystems to more complex, integrated approaches such as the degree of naturalness and the habitat value, and we stressed preference analyses and monetary methods like the Habitat Valuation Method and valuation based on restoration costs.

Thus, we included methods belonging to the three broad perspectives on valuing biodiversity that cover ecological, socio-cultural and economic benefits of biodiversity as distinguished in the Millennium Ecosystem Assessment (MA, 2005) and TEEB (2010). This is also in line with the three main approaches of valuing biodiversity in environmental management proposed by Laurila-Pant et al. (2015), where the first approach is to value biodiversity in terms of the services provided for society, while the second approach is to assess socio-cultural values; the last approach adopts a biological viewpoint. 


\section{Results}

\section{Ecological indicator approaches}

Counting and mapping of rare/protected species. Recording and mapping of animal and plant species is a very common tool, the application of which is driven mainly by legal means (national nature conservation acts, European regulations, e.g., Natura 2000). A special focus is placed on species being protected and/or endangered (red list species).

According to German legislation, it is not allowed to kill or destroy native

animals and plants without reasonable cause. There are also categories of special or strict protection: Among animals, all native bird species (except, e.g., feral domestic pigeons) and bats, including their habitats, are protected, many mammals, all reptiles, amphibians, but also fishes and insects are included. That means, it is not allowed to pursue or even kill them. A similar situation obtains in the Czech Republic, where all autochthonous species of plants and animals are protected if they do not occur on land to be managed in a standard manner.

Development planning is obliged to take care of protected species. Such plans have

to lay down avoidance measures (planning alternatives, construction field preparation outside the breeding season) and compensation. Measures to ensure the Continuous Ecological Functionality (CEF) are obligatory; they must be implemented completely before the construction works are started, for example, creation of substitute habitats for birds, sand lizards, rare beetles and butterflies (EEC, 2007).

There are various data sources for species, mainly faunistical and floristical maps and publications. In many cases, however, the data are incomplete, not up to date or at an inappropriate scale. Thus, it is often necessary to engage consultants to analyse the occurrence of (particularly European) protected species in a planned development area and to draw conclusions for protection, avoidance and compensation measures.

An important data source for biodiversity issues (among them species and habitats) in both countries is the landscape plan, which is defined as the expert planning of nature conservation and landscape management (Haaren, Albert, 2011; Riedel et al., 2016). Vice versa, the landscape plan needs to be fed with biodiversity data (Bastian, 1998). To a large extent, the landscape plan covers the spatial dimension, which is very important for biodiversity conservation and management.

The landscape plan is an important document that gives an overview of habitat/biotope issues and provides a framework for conservation and management. Both landscape plan of Dresden and urban plan of Liberec are similar in the basic content. But there are several specific features, partly indicated below. For example, the landscape plan of Dresden (Landschaftsplan Dresden, 2018) refers to

- $\quad$ animals, plants, especially rare and protected species,

- historical woodlots (valuable for specialized animal species),

- highly valuable woods,

- biotope compound systems, habitat connectivity: core areas of habitat connection and species diversity, corridors and stepping stones (similar to the USES concept of the Czech Republic and Slovakia) (Diviaková et al., 2018), 
- core areas for protected building-inhabiting animal species,

- conservation measures for amphibians along roads,

- precautionary assessment of species populations before the implementation of measures designed in the landscape plan,

- maintenance and improvement of habitats of ground-nesting bird species on arable fields and meadows,

- $\quad$ deficits and threats to protected areas, species, habitats and connectivity (e.g., barriers). In the urban plan of Liberec (City plan Liberec, 2019), special emphasis is placed on

- $\quad$ significant elements of ecological stability,

- urban greenery,

- $\quad$ scattered greenery in the landscape,

- peripheral forest landscape,

- territorial system of ecological stability (USES),

- landscape character.

Both landscape plans are similar concerning nature protection in general, but the Dresden plan puts greater emphasis on protecting biodiversity, while the Liberec plan focuses primarily on supporting environmental stability.

\section{Vegetation}

Vegetation can be regarded as the most conspicuous biotic component of a terrestrial area. We distinguish between current vegetation and actual potential natural vegetation (Tüxen, 1956). The actual vegetation is shaped by natural conditions and land use. The potential natural vegetation is defined as the vegetation representing the abiotic site conditions (including all essential irreversible changes) as a manifestation of the abiotic environment. The comparison of the actual vegetation and the potential natural vegetation enables the assessment of the actual changes in the vegetation, particularly the extent of human impact. An indicator for this difference is the naturalness of vegetation (e.g., after Schlüter, 1982, 10 degrees), or reciprocally the hemeroby (Table 1 ).

For the differentiation of nature in cities, the degrees of hemeroby, synanthropy and naturalness are suitable indicators (Table 1).

In view of naturalness or human influence, Kowarik, Körner (2005) distinguished four basic forms of nature found in cities:

- Nature 1 'old wilderness': remnants of pristine nature,

- Nature 2 'traditional cultural landscape': continuity of former agricultural or forested land,

- Nature 3 'functional greening': urban parks, green areas and gardens,

- Nature 4 'urban wilderness': new elements from natural colonization processes, particularly distinct on urban wastelands.

With the aim of achieving a comprehensive evaluation of urban nature, an additional form Nature 5 'artificial and unnatural elements' (e.g., buildings, green roofs) was developed within the framework of the project. This form of nature encompasses heavily sealed or builtup areas, which may also be partially greened, but can still be regarded as predominantly 
T a b l e 1. Hemeroby of vegetation (modified after Blume, Sukopp, 1976; Bastian, Schreiber, 1999).

\begin{tabular}{|l|l|l|}
\hline Hemeroby & $\begin{array}{l}\text { Anthropogenic vegetation } \\
\text { changes }\end{array}$ & Ecosystem types (examples) \\
\hline Ahemerobic & None & Remnants of pristine nature \\
\hline Oligohemerobic & Rather low/few & Near-natural forests, bogs \\
\hline Mesohemerobic & Medium & $\begin{array}{l}\text { Semi-natural or more artificial forests, heaths, dry and rough } \\
\text { meadows, extensively used meadows and pastures }\end{array}$ \\
\hline$\beta$-euhemerobic & Strong & $\begin{array}{l}\text { Intensively used grassland and forests, perennial ruderal } \\
\text { vegetation, segetal communities (on arable fields) }\end{array}$ \\
\hline a-euhemerobic & Very strong & $\begin{array}{l}\text { Special cultures (orchards, vineyards, ornamental lawns), an- } \\
\text { nual pioneer and ruderal vegetation }\end{array}$ \\
\hline Polyhemerobic & Extremely strong & $\begin{array}{l}\text { Waste deposits, spoil heaps, paved paths, gravelled railroad } \\
\text { tracks }\end{array}$ \\
\hline Metahemerobic & Vegetation totally removed & $\begin{array}{l}\text { Poisoned ecosystems, totally built-up/sealed areas (buildings, } \\
\text { tar surface) }\end{array}$ \\
\hline
\end{tabular}

artificial in the overall urban context. Although this type of urban nature is not nature in the 'classical' sense, it should nevertheless be regarded as a potential ecosystem, and thus, a potential provider of habitats for different species, e.g., plants. Thus, areas are also included that would not have been considered according to the four basic forms of nature according to Kowarik, Körner (2005).

By means of the extended classification of urban areas with regard to their form of nature, as shown in Fig. 1, as an example for Dresden, areas can be identified in which there is urban planning potential with regard to preserving nature (Nature 1 and 2). These kinds of area can be identified, for example, within the areas of the urban forest 'Dresdner Heide' or along the Elbe river (see Fig. 1). Additionally, this classification shows parts of the city where upgrading measures could be necessary (Nature 4 and 5). Furthermore, the spatial distribution of urban nature forms shows where an increased need for horticultural maintenance (Nature 3) and an increased demand for the provision of habitats for a possible promotion of biodiversity (Nature 4 and 5) can be expected. The latter occur especially in the city centre of Dresden (see Fig. 1). Thus, the extended urban nature approach according to Kowarik, Körner (2005) is interesting for assessing the existing nature forms in a city and for identifying areas with special need regarding the promotion and preservation of urban biodiversity.

\section{Classification of land cover data (biotope and land use mapping)}

Land cover maps showing type and intensity of land use combined with biotope types are widely distributed and frequently applied. Land cover data include indicators that can be used to characterize human impact on the territory and correspondingly the degree of naturalness. This data type can also serve to roughly characterize vegetation and can indicate the site conditions crucial for organisms, for example, estimate the intensity of human influence on the microclimatic conditions of the vegetation cover and on the habitat structures for wild plants and animals. Moreover, land cover data imply causal ecological networks and running processes. Therefore, one can obtain the frequency and distribution of all habitat types 


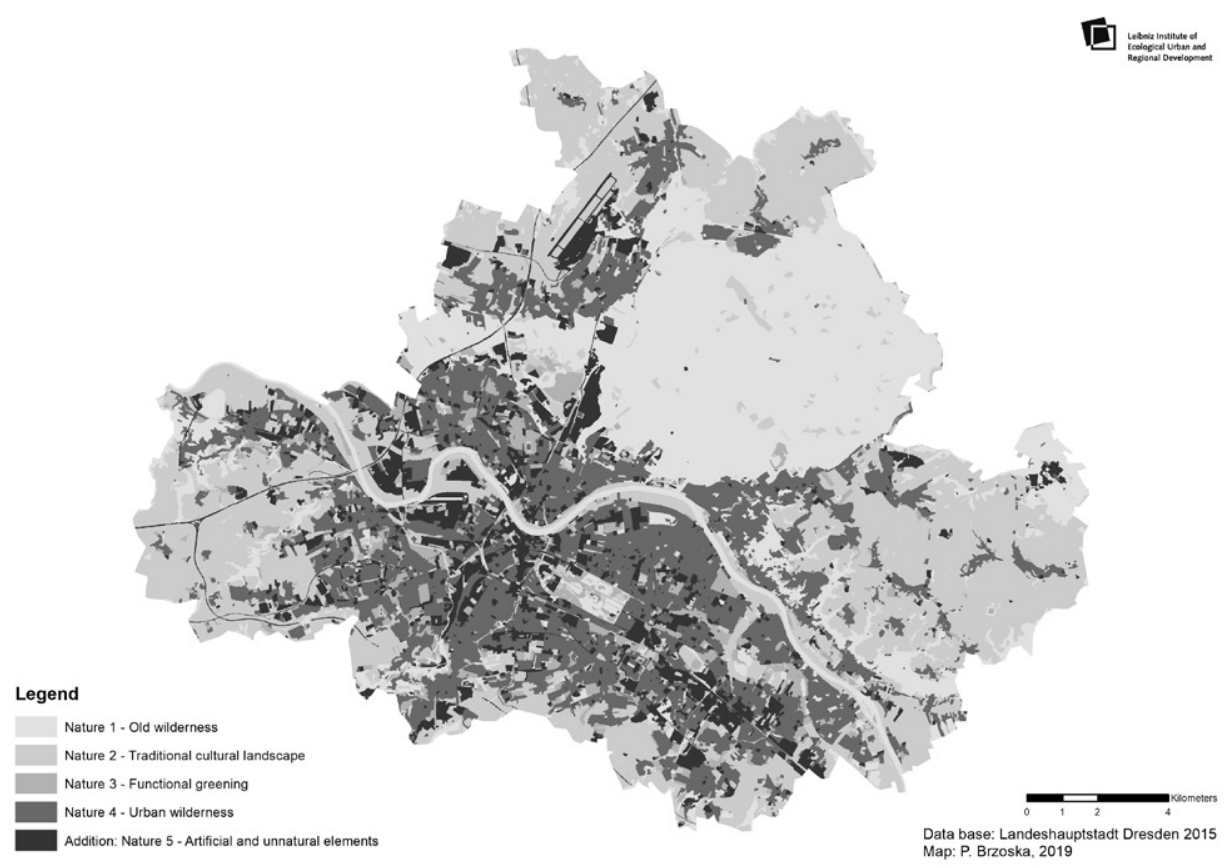

Fig. 1. Five basic forms of nature in cities (after Kowarik, Körner, 2005, modified).

$\mathrm{T}$ a b 1 e 2. Classification of habitat types (role for biodiversity and habitat function) -5 degrees ( 1 - the highest; 5 - the lowest) (according to Bastian, Schreiber, 1999).

\begin{tabular}{|l|c|}
\hline Habitat/land use type & Habitat value \\
\hline Deciduous forest & 1 \\
\hline Humid/wet forest & 1 \\
\hline Mixed forest & 1.5 \\
\hline Coniferous forest & 2 \\
\hline First afforestation & 2 \\
\hline Tree row, alley & 2.5 \\
\hline Hedge & 2 \\
\hline Orchard meadow & 1 \\
\hline Dry, nutrient-poor grassland & 1 \\
\hline Wet grassland, moist ruderal area & 2 \\
\hline Grassland, dry ruderal area & 2.5 \\
\hline Fields, arable land & 4 \\
\hline River & 2.5 \\
\hline Riparian vegetation & 1 \\
\hline Pond & 1 \\
\hline Sports, leisure area & 3.5 \\
\hline Industrial site & 4.5 \\
\hline Open building area & 3 \\
\hline Dense urban development & 5 \\
\hline Road & 5 \\
\hline
\end{tabular}

of an area as well as information on their naturalness.

The landscape plan of Dresden includes habitats and land cover maps that are based on Colour Infrared Photographs (CIR). These data identify about 100 different habitat types, which can be further differentiated by structural and additional features (primary scale 1:5,000, generalized 1:50,000), and can be combined with 19 comprehensive habitats and land use complexes. By classifying the habitat or land cover types with regard to their suitability for being habitats of flora and fauna (and for hosting a rich biodiversity), it is possible to identify habitat values (see Table 2).

The classification of the habitat and land cover types in the city of Dresden shows the amount and the distribution of areas that exhibit high to low habitat val- 


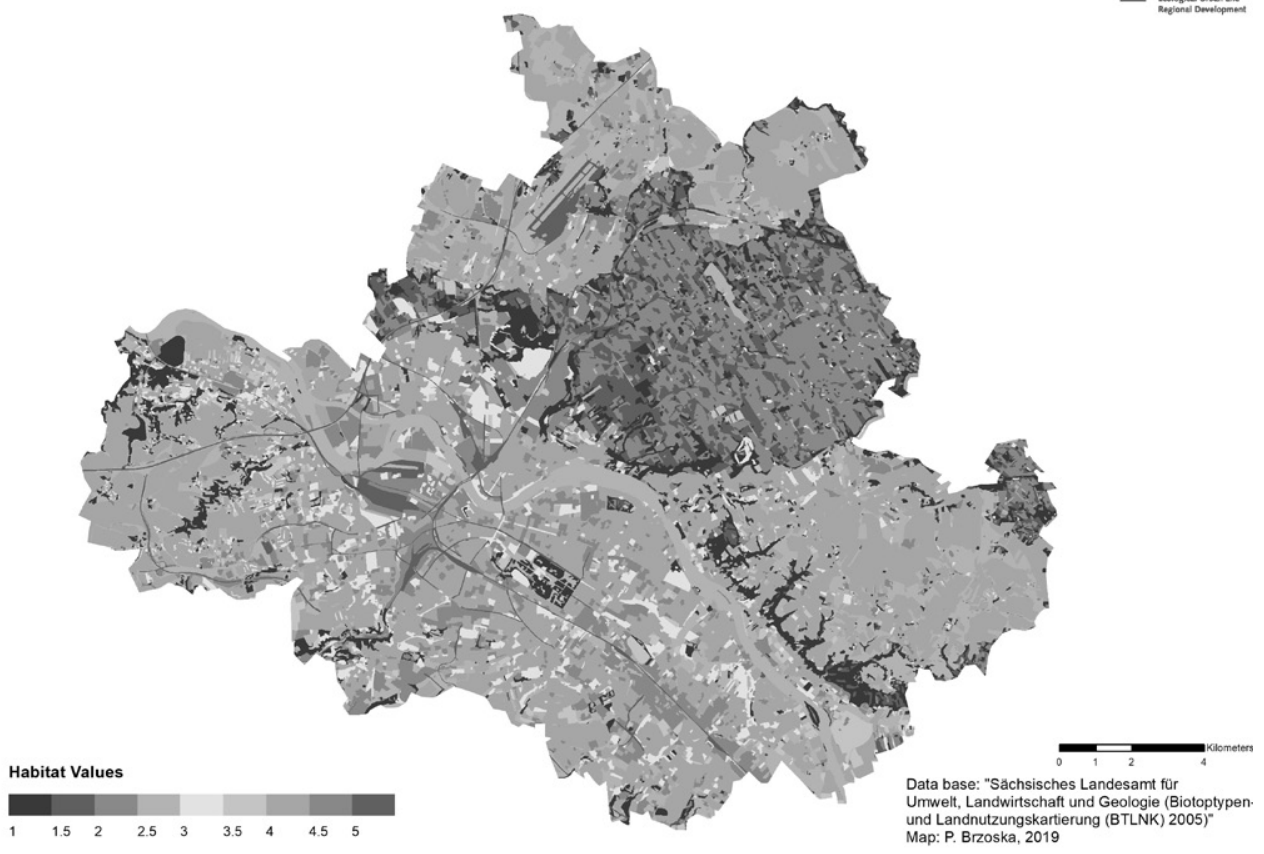

Fig. 2. Values of habitat and land cover types in the city of Dresden (green colour and low numbers: highest values, orange and red colour and high numbers: lowest values; see Table 2).

ues, and therefore, indicates their significance for the protection and preservation of biodiversity in the city (Fig. 2). Areas with the highest habitat values are in the northern part of Dresden (dark and light green areas). These areas include mainly large forest territories, such as the Dresdner Heide, as well as agricultural regions in the outskirts. But small patches within urban parks, as indicated in the Großer Garten in the city centre, may also exhibit high biotope values and can be seen as important near-natural habitats. The lowest habitat values (dark red areas) are located in the central parts of Dresden with high soil sealing and very high human influence. But in general, most of the city area is classified with low habitat values (orange areas).

\section{Protected areas}

Settlements can host important substitute habitats for various threatened species of natural and cultural landscapes (Müller, Abendroth, 2007). Following the principle of differentiated land use and nature conservation intensities (Haber, 1998) across the entire territory, protecting biodiversity in urban areas must include all categories of nature, from the remnants of natural landscapes (e.g., near-natural forests), cultural landscapes (orchards), urban-industrial areas including rural settlements and landscaped areas. The core areas of nature conservation, however, are represented by various legally protected areas, also in cities. 
The conservation status implies - as a rule - the high value of an area in terms of biodiversity (and habitat services) but also a higher priority in planning and decision-making. We can find various categories of protected areas and objects in the cities of Dresden and Liberec (Table 3). There are also sites of the EU-wide Natura 2000 network, which is designed to help achieve the goal of the European Union of 'halting the loss of biodiversity and the degradation of ecosystem services in the EU by 2020, and restoring them in so far as feasible, while stepping up the EU contribution to averting global biodiversity loss' (COM, 2011). Natura 2000 comprises two basic categories: (especially and strictly) protected species and protected areas - FFH sites (Fauna-Flora-Habitat Sites $=$ Special Areas of Conservation pursuant to the Habitats Directive 21.5.1992, 92/43/EWG), and Special Protection Areas (SPA, pursuant to the Wild Birds Directive 2. April 1979, 79/409/EWG).

T a b l e 3. Nature conservation areas and objects in Dresden and Liberec (Schutzgebiete Dresden, 2018; AOPK, 2011).

\begin{tabular}{|l|c|c|}
\hline & Dresden & Liberec \\
\hline Total size of the territory & $328.28 \mathrm{~km}^{2}$ & $10.61 \mathrm{~km}^{2}$ \\
\hline Nature reserves & $248 \mathrm{ha}$ & $71 \mathrm{ha}$ \\
\hline Natural monuments & $134 \mathrm{ha}$ & $35 \mathrm{ha}$ \\
\hline Landscape protection areas & $12,238 \mathrm{ha}$ & 1,460 ha \\
\hline Protected habitats & $1,470 \mathrm{ha}$ & \\
\hline Valuable trees & c. 1,950 individuals & 1 ha \\
\hline FFH & 1,901 ha & \\
\hline SPA & 1,609 ha & \\
\hline
\end{tabular}

Unlike comprehensive habitat and land cover mapping, selective habitat mapping considers only for valuable (and protected) habitats (partly synonymous: biotopes) (Cudlín et al., 2005).

Examples of legally protected habitat types in Germany are natural running and standing waters, including their riparian vegetation, bogs, swamps and reeds, dunes, heaths, bogs, swamp and riverside forests, natural rocks, natural coast areas; in Saxony and some other German federal states additionally, for example, nutrient-poor fresh and mountain meadows, hollow trees, orchard meadows, clearance cairns, ravines and dry walls. As an additional category, the landscape plan of Dresden also mentions 'complex of habitats or land use types with great significance for biodiversity' (three-grade scale: medium, high, very high).

\section{Economic valuations}

Biodiversity is not only an ecological, but also a social and economic issue (Laurila-Pant et al., 2015). Economic valuations of biodiversity/ecosystems in cities are still not very common. They are of great significance, particularly in terms of cost calculations for compensation measures (for species and habitats) and for landscape management.

Habitat values are used in the framework of the Impact Mitigation Regulation (Albrecht et al., 2014) for comparison and compensation purposes. These values are regarded as physi- 
cal indicators for the performance of an ecosystem to maintain biodiversity, or - depending on the specific application - as part of the physical capital value of an ecosystem. First, this value is non-monetary, but it has the characteristics of exchange values, which can easily be transformed to monetary values.

Monetary values for habitat types are also used in the Impact Mitigation Regulation. If values and functions of nature are impaired by an avoidable impact (e.g., by construction measures), the damage can be calculated as the equivalent of the costs of compensation (substitution and compensation costs) or replacement measures (replacement costs) necessary for the recovering of the functions of nature. The starting point for the derivation of monetary values are nature conservation requirements on the extent of compensation and replacement measures (compensation obligation, German Nature Conservation Act \$8). This obligation can be seen as the consensus of society to maintain the functions of nature (or the ecosystem services). The compensation cost is adequate to society's willingness-to-pay.

This ties to the Habitat Equivalency Investment Model (Schweppe-Kraft, 2009), which calculates the restoration costs while taking the necessary time or duration of development into account. In a similar vein, Seják et al. (2003) created a Habitat Valuation Method (HVM) for habitat type quality assessment, which combines the expert and habitat-specific restoration cost assessment (Table 4). They awarded scores between 1 and 6 for each of the criteria phylogenetic maturity of vegetation, habitat naturalness, structure diversity, species diversity, rarity of the habitat type, rarity of species, habitat vulnerability, and threat to habitat type (Seják, Cudlín, 2010). The financial value of one point corresponds to the arithmetic mean of the costs of analysed restoration projects in the Czech Republic spent to improve the ecological state of $1 \mathrm{~m}^{2}$ by one point. In 2003, the authors assigned monetary values to the score (1 point $=0.40 €$ ); by 2015 , it had increased due to inflation to $0.59 €$ (Pechanec et al., 2017); and in 2018, it was re-counted using new restoration projects and reached $1.14 €$.

Using the Habitat Valuation Method, a total habitat value of $106,087,048 €$ was found in the Liberec cadastral territory. The total value for $1 \mathrm{~m}^{2}$ was $22.3 €\left(220,300 € \mathrm{ha}^{-1}\right)$, which means that the annual value was $1.12 € \mathrm{~m}^{-2}\left(10,000 € \mathrm{ha}^{-1}\right.$ year $\left.^{-1}\right)$. It must be stated, however,

T a b l e 4. Habitat types and their monetary values in the Czech Republic, calculated with the Habitat Valuation Method (Pekanec, unpublished data).

\begin{tabular}{|c|c|c|c|c|}
\hline Habitat & Name & $\begin{array}{c}\text { Area in CR } \\
\left(\mathbf{k m}^{2}\right)\end{array}$ & Point value & $\begin{array}{l}\text { Monetary value } \\
\text { (EUR) of } 1 \mathrm{~m}^{2}\end{array}$ \\
\hline T1.1 & Mesic Arrhenatherum meadows & 1907.16 & 33 & 37.62 \\
\hline L5.1 & Herb-rich beech forests & 1229.30 & 45 & 51.30 \\
\hline L3.1 & Hercynian oak-hornbeam forests & 1010.61 & 47 & 53.58 \\
\hline $\mathrm{L} 2.2$ & Ash-alder alluvial forests & 796.06 & 42 & 47.88 \\
\hline L9.1 & Montane Calamagrostis spruce forests & 438.81 & 36 & 41.04 \\
\hline T1.5 & Wet Cirsium meadows & 416.78 & 49 & 55.86 \\
\hline T1.3 & Cynosurus pastures & 408.56 & 39 & 44.46 \\
\hline K3 & Tall mesic and xeric scrub & 351.90 & 33 & 37.62 \\
\hline $\mathrm{L} 2.3$ & Hardwood forests of lowland rivers & 241.38 & 66 & 75.24 \\
\hline L4 & Ravine forests & 209.34 & 42 & 47.88 \\
\hline
\end{tabular}


that such monetary calculations with the Habitat Valuation Method have rarely been applied in practical work.

As nature conservation and habitat management are nearly always limited by scarce monetary resources, the description of biodiversity in monetary terms is useful, particularly in terms of the costs for maintaining, managing and restoring valuable habitats.

Grunewald et al. (2014) developed a methodology for a regional (state-wide) calculation of landscape management measures and costs. It was compiled in an exemplary manner for the Federal State of Saxony (c. $18,420 \mathrm{~km}^{2}$ ) in Germany. Table 4 shows an example for the city of Dresden. Costs of habitat management are required to plan landscape management and nature conservation measures. They would also be useful to calculate (and demand) a budget, which truly reflects the total annual expense of maintaining (and developing) valuable biotopes (Table 5).

$\mathrm{T}$ a b 1 e 5. Annual management costs for valuable biotopes in the city of Dresden, Germany (after Grunewald, Syrbe, 2013; Geißler, 2017, modified).

\begin{tabular}{|l|l|c|c|c|}
\hline Acronym & Biotope type & $\begin{array}{c}\text { Total } \\
\text { area (ha) }\end{array}$ & $\begin{array}{c}\text { Ann. costs } \\
€ / \text { ha }\end{array}$ & $\begin{array}{c}\text { Ann. costs } \\
€ / \text { habitat type }\end{array}$ \\
\hline BS & Orchard meadows & 278.4 & 600 & 167,040 \\
\hline GM & Extensively used nutrient-poor mesophilic grassland & 264.0 & 413 & 109,032 \\
\hline RS & Acid dry grassland & 40.0 & 520 & 20,800 \\
\hline & All protected biotope types in Dresden & 1,470 ha & & $\begin{array}{c}702,844 \\
\text { (total costs) }\end{array}$ \\
\hline
\end{tabular}

For ecosystem service assessments, the biophysical accounting is only one side of the coin. It represents only the biophysical basis or the supply side. It should be complemented by demand-oriented approaches that relate more to the perspective of users and beneficiaries. In the broadest sense, such preference analyses are also economic valuation methods.

\section{Public appreciation of urban biodiversity}

People place value on species, ecosystems and biodiversity in general as well as on ecosystem services without necessarily assigning monetary values. There are a lot of methods for expressing preferences in non-monetary yet quantifiable terms, including quantitative and qualitative techniques (i.e., surveys, interviews), participatory and deliberative tools (e.g., Hofmann et al., 2012; Botzat et al., 2016; Moyzeová, 2018). A recent representative study by Fischer, Kowarik (2018) regarding a question on the appreciation of urban species-diversity through people in the city indicates that a high degree of biodiversity in urban environments is accepted and supported the most. In this study, about 4000 people in five different European countries with diverse backgrounds were interviewed and asked about their preferences.

In recent years, a number of structured surveys have been carried out in Dresden, for example, in relation with urban climate adaptation and green spaces, the restoration of an urban watercourse (Geberbach), the design of an urban park (Südpark) or the upgrading of 
urban green spaces. The results of all these surveys reflected the public's high regard for biological diversity and the ecosystem services associated with it.

As part of the BIDELIN project, surveys on the perception of urban ecosystem services and their impact on well-being were carried out in the summer months of 2018. A total of 217 Dresden citizens were interviewed in various parks in the city. The assessment of decisions on important ecosystem functions and services, which can, for example, be provided by city parks, shows the high importance of biodiversity-related ecosystem services for the inhabitants (see Table 6). The most frequent choices (94 to $92 \%$ ) relate to habitat services that parks can provide for plants, animals or bees. Only 'recreation' (99\%) and 'improvement of air quality' $(96 \%)$ were chosen more frequently.

T a b le 6. Assessment of choices concerning important ecosystem services and functions provided by Dresden city parks $(n=217)$.

\begin{tabular}{|l|c|}
\hline Ecosystem services and functions & "Very important" \\
\hline Recreation & $99 \%$ \\
\hline Improvement of the air quality & $96 \%$ \\
\hline Habitat for plants & $94 \%$ \\
\hline Habitat for animals & $92 \%$ \\
\hline Habitat for bees (pollination) & $92 \%$ \\
\hline Improvement of microclimate (shadowing, cooling, air humidity) & $89 \%$ \\
\hline$\ldots$ & $\ldots$ \\
\hline
\end{tabular}

The planning process of an urban park in Dresden, the so-called Südpark, can be considered as another example of the high valuation of biodiversity and thus the significant role of biodiversity in the city. Citizens were involved in this process and have been asked about their wishes for the park design and park facilities. Many aspects related to biodiversity emerged among the most common responses. The most frequently stated demand was the plantation of an orchard meadow with fruit trees, which is a legally protected biotope type in Saxony (see 3.1.4.). Further common demands concerned the creation of 'untouched' natural areas and the maintenance of meadows.

\section{Discussion and conclusion}

The aim of the study was to find which role methods to analyse and valuate biodiversity in its different dimensions play in urban nature conservation, city planning and decision-making.

Looking at the practice of planning and decision-making in cities on the example of Dresden and Liberec, we see a broad variety of tools applicable on different scales for various more or less complex tasks. As Chevassus-au-Louis et al. (2009) note, the quantification of biodiversity is a particularly ambitious goal, and the desire to define a simple and unique indicator analogous to the 'ton of coal equivalent' is an illusion, as is any definition of a monetary indicator to account for all of the aspects of biodiversity. The very specific nature of local situations also makes value transfers problematic. 
Among the various methods, the classification of land cover data according to the habitat values by Bastian, Schreiber (1999) shows an easily applicable method for obtaining an overview of the spatial distribution of areas and their share with regard to their significance for biodiversity. The 'classical' biodiversity indices (or functions that take into account the relative frequencies of species present at the site), which describe the richness and distribution of species, do not play a major role.

Methods related to species and areas enjoying legal protection, however, have the highest significance for the practitioners in city administration. In daily planning and decision practice, such species and areas absolutely have to be taken into consideration. In principle, adequate methods have proven their worth, although enhancements by better data and knowledge progress are possible.

As Laurila-Pant et al. (2015) note, for all the classical indicators, threshold levels can be set, which dictate the minimum level of biodiversity to maintain. These thresholds serve as the minimum level of biodiversity that society seeks to preserve. Therefore, defining such a threshold represents the first social aspects of the analyses. Overall, these ecological biodiversity indicators are useful quantitative tools for assessing the state of biodiversity, as well as for communicating complex environmental issues in order to integrate them more thoroughly into policy decisions (TEEB 2010).

Despite the numerous advantages of the ecosystem services concept (e.g., De Groot et al., 2010; Ring et al., 2010; Spangenberg, Settele, 2010; Haaren, Albert, 2011; Matzdorf et al., 2019), the application of the ecosystem services concept is (still) not widespread in city planning and decision-making (including in Dresden and Liberec). Of course, meanwhile the concept is more or less broadly accepted, but primarily among scientists and some politicians. There is also increasing consensus that ecosystem services are a basic prerequisite for the quality of life in cities, and that for the future well-being of citizens, the quality and functions of urban ecosystems need to be improved.

To some degree, economic valuation of biodiversity and ecosystem services is used nevertheless, namely for the calculation of economic expenditures of ecosystem management. Thus, nature conservation efforts can be made financially sustainable over longer periods of time, also in cities (Mertz et al., 2007; Seják, Cudlín, 2010; Spangenberg, Settele, 2010).

The knowledge of economic (monetary) values in a strongly economically oriented world can also be helpful for awareness raising and for improving weighing decisions. It can produce a 'wow' effect when one hears that the annual economic value of FFH sites in the city of Dresden $(1,901 \mathrm{ha})$ is $4.6-6.5$ million $€ / \mathrm{a}$, and that of protected biotopes $(1,470 \mathrm{ha})$ ranges between 3.6 and 5.1 million $€ /$ a. We downscaled the data calculated for the entire Natura 2000 network of the EU (annual value 2,447 €/ha (median) -3,441 (mean) (see IEEP, 2002; Kettunen et al., 2009; Gantioler et al., 2010; Bastian, 2013). It is obvious that the benefit of these protected areas exceeds the costs for habitat management (Table 5) by far.

Our preference studies showed the high appreciation of urban biodiversity by the citizens of Dresden. This is in line with indications from literature that reflect a high importance and perception of biodiversity in cities for the citizens (e.g., Botzat et al., 2016; Fischer, Kowarik, 2018).

We conclude that the existing methods of analysing and accounting for biodiversity and habitat services may provide a valuable knowledge base for decision-making, plan- 
ning, nature conservation and management (not only) in cities. In most cases, only few selected methods are applied, depending on the object of investigation, data availability and costs. Laurila-Pant et al. (2015) argue for more integrative approaches that consider all three perspectives of biodiversity valuation. According to Ring, Schröter-Schlaack (2011), to achieve sustainable solutions in biodiversity conservation we need policy mixes consisting of a broader range of assessment and valuation methods. They should include biophysical ranking methods but also integrated approaches that consider the complexity of ecological, social and economic systems, among them measures of attitudes, preferences and intentions, civic valuation, ecosystem benefit indicators, and negotiations among stakeholders.

\section{References}

Albrecht, J., Schumacher, J. \& Wende W. (2014). The German impact-mitigation regulation - A model for the EU's no-net-loss strategy and biodiversity offsets? Environmental Policy and Law, 44(3), 317-332.

AOPK (2011). Data about area of protected territories.http://www.nature.cz/publik_syst2/files/udaje_o_rozloze_biotopu_cr.pdf

Bastian, O. (1998). Landscape-ecological goals as guiding principles to maintain biodiversity at different planning scales. Ekológia, Bratislava, 17(1), 49-61.

Bastian, O. (2013). The role of biodiversity in supporting ecosystem services in Natura 2000 sites. Ecological Indicators, 24, 13-22. DOI: 10.1016/j.ecolind.2012.05.016.

Bastian, O. \& Schreiber K.-F. (Eds.) (1999). Analyse und ökologische Bewertung der Landschaft. Heidelberg, Berlin: Spektrum Akademie Verlag.

Bastian, O. \& Xiao N. (2018). The role of biodiversity in a city. In K. Grunewald, J. Li, G. Xie \& L. Kümper-Schlake (Eds.), Towards green cities. Urban biodiversity and ecosystem services in China and Germany (pp. 49-55). Cham: Springer International Publishing. DOI: 10.1007/978-3-319-58223-8.

Blume, H.-P. \& Sukopp H. (1976). Ökologische Bedeutung anthropogener Bodenveränderungen. Schriftenreihe für Vegetationskunde, 10, 75-89.

Botzat, A., Fischer, L.K. \& Kowarik I. (2016). Unexploited opportunities in understanding liveable and biodiverse cities. A review on urban biodiversity perception and valuation. Global Environmental Change, 39, 220-233. DOI: 10.1016/j.gloenvcha.2016.04.008.

Chevassus-au-Louis, B., Salles, J.-M., Bielsa, S., Richard, D., Martin, G. \& Pujol J.-L. (2009). Approche économique de la biodiversité et des services liés aux écosystèmes. Paris: Rapport du CAS.

City plan Liberec (2019). City plan of the statutory city of Liberec. https://www.liberec.cz/cz/radnice/strategie-projekty/uzemni-plan/uzemni-planovani/uzemni-plany-obci/liberec/platny-uzemni-plan/

COM (2011). Final communication from the commission to the European Parliament, the Council, the Economic and Social Committee and the Committee of the Regions: Our life insurance, our natural capital: an EU biodiversity strategy to 2020. Brussels: European Commission.

Cudlín, P., Prokopová, M., Francírková, T., Burešová, R., Smrž, T. \& Boucníková E. (2005). System NATURA 2000 utilization for purposes of biotope valuation. Ekológia (Bratislava), 24(Suppl. 1), 52-68.

de Groot, R.S., Alkemade, R., Braat, L., Hein, L. \& Willemen L. (2010). Challenges in integrating the concept of ecosystem services and values in landscape planning, management and decision making. Ecological Complexity, 7(3), 260-272. DOI: 10.1016/j.ecocom.2009.10.006.

Diviaková, A., Kočická, E., Belčáková, I. \& Beláňová E. (2018). Evaluation of the significance of linear non-forest woody vegetation in the development of an ecological network. Applied Ecology and Environmental Research, 16(2), 1221-1241. DOI: 10.15666/aeer/1602_12211241.

EEC (2007). Guidance document on the strict protection of animal species of Community interest under the Habitats Directive 92/43/EEC 2007. http://ec.europa.eu/environment/nature/conservation/species/guidance/pdf/guidance_en.pdf

Fischer, L.K. \& Kowarik I. (2018). Urbane Artenvielfalt ist beliebt! Gesellschaftliche Unterstützung für eine vielfältige Natur im besiedelten Bereich. GIT Labor-Fachzeitschrift, 12, 24-27. 
Gantioler, S., Rayment, M., Bassi, S., Kettunen, M., McConville, A., Landgrebe, R., Gerdes, H. \& ten Brink P. (2010). Costs and socio-economic benefits associated with the Natura 2000 network. Final Report to the European Commission, DG Environment, Institute for European Environmental Policy/GHK/Ecologic, Brussels.

Geißler, M. (2017). Bilanzierung der Landschaftspflege im urbanen Raum am Beispiel der Städte Chemnitz, Dresden und Leipzig. Unpubl. Master thesis, Technical University, Dresden.

Grunewald, K. \& Syrbe R.-U. (2013). Bilanzierung von ausgewählten Leistungen und Anforderungen der Landschaftspflege in Sachsen aus landesweiter Sicht. Dresden: Sächsisches Landesamt für Umwelt, Landwirtschaft und Geologie.

Grunewald, K., Syrbe, R.-U. \& Bastian O. (2014). Landscape management accounting as a tool for indicating the need of action for ecosystem maintenance and restoration - exemplified for Saxony. Ecological Indicators, 37(A), 241-251. DOI: 10.1016/j.ecolind.2013.09.014 .

Grunewald, K. \& Bastian O. (2017). Maintaining ecosystem services to support urban needs. Sustainability, 9(1647), 9. DOI:10.3390/su9091647

Haaren, C.V. \& Albert C. (2011). The concepts of ecosystem services and environmental planning: An assessment of the scope for synergies. International Journal of Biodiversity Science, Ecosystem Services \& Management, 7(3), 150-167. DOI: 10.1080/21513732.2011.616534.

Haber, W. (1998). Das Konzept der differenzierten Landnutzung - Grundlage für Naturschutz und nachhaltige Naturnutzung. Bundesministerium für Umwelt, Naturschutz und Reaktorsicherheit (Ed.), Ziele des Naturschutzes und einer nachhaltigen Naturnutzung in Deutschland (pp. 57-64). Bonn: BMU.

Haines-Young, R. \& Potschin M.B. (2018). Common International Classification of Ecosystem Services (CICES) V5.1 and Guidance on the Application of the Revised Structure. https://cices.eu/content/uploads/sites/8/2018/01/ Guidance-V51-01012018.pdf

Hofmann, M., Westermann, J.R., Kowarik, I. \& Van der Meer E. (2012). Perceptions of parks and urban derelict land by landscape planners and residents. Urban Forestry \& Urban Greening, 11(3), 303-312. DOI: 10.1016/j. ufug.2012.04.001.

IEEP (ten Brink, P., Monkhouse, C. \& Richartz S.) (2002). Promoting the socio-economic benefits of Natura 2000. Background Report, Institute for European Environmental Policy (IEEP), European Conference, Brussels, November 28-29, 2002.

IÖR (2019). The BIDELIN project. http://bidelin.ioer.eu/en/Kettunen, M., Bassi, S., Gantioler, S. \& ten Brink P. (2009). Assessing socio-economic benefits of Natura 2000 - a toolkit for practitioners. Brussels: Institute for European Environmental Policy (IEEP).

Kowarik, I. \& Körner S. (2005). Wild urban woodlands. New perspectives for urban forestry. Heidelberg: Springer.

Landschaftsplan Dresden (2018). The landscape plan of the capital city of Dresden. http://www.dresden.de/de/ stadtraum/umwelt/umwelt/landschaftsplan/geltender_landschaftsplan.php

Laurila-Pant, M., Lehikoinen, A., Uusitalo, L. \& Venesjärvi R. (2015). How to valuate biodiversity in environmental management? Ecological Indicators, 55, 1-11. DOI: 10.1016/j.ecolind.20153.02.034.

MA (2005). Millennium Ecosystem Assessment. Ecosystems and Human Well-Being. Washington, D.C.: Island Press.

Mace, G.M., Norris, K. \& Fitter A.H. (2012). Biodiversity and ecosystem services: a multilayered relationship. Trends Ecol. Evol., 27(1), 19-26. DOI: 10.1016/j.tree.2011.08.006.

Matzdorf, B., Hansjürgens, B., Lienhoop, N., Schröter, B., Schröter-Schlaack, C., Stöcker, U., Suntken, S. \& Szallies I. (2019). Erkenntnisse aus dem TEEB-Deutschland-Prozess für die Politikgestaltung in ländlichen Räumen nutzen. Handlungsempfehlungen am Beispiel dreier Politikfelder. Natur und Landschaft, 94(1), 21-27. DOI: 10.17433/1.2019.50153657.21-27.

Mertz, O., Ravnborg, H.M., Lövei, G.L., Nielsen, I. \& Konijnendijk C.C. (2007). Ecosystem services and biodiversity in developing countries. Biodivers. Conserv., 16(10), 2729-2737. DOI: 10.1007/s10531-007-9216-0

Moyzeová, M. (2018). Inclusion of the public in the natural capital, ecosystem services and green infrastructure assessments (Results of structured interviews with stakeholders of commune Liptovská Teplička). Ekológia (Bratislava), 37(1), 42-56. DOI: 10.2478/eko-2018-0005.

Müller, N. \& Abendroth S. (2007). Empfehlungen für die Nationale Strategie zur Biologischen Vielfalt in Deutschland. Naturschutz und Landschaftsplanung, 39, 114-118.

Pechanec, V., Machar, I., Štěrbová, L., Prokopova, M., Kilianova, H., Chobot, K. \& Cudlín P. (2017). Monetary valuation of natural forest habitats in protected areas. Forests, 8, 427. DOI: 10.3390/f8110427.

Riedel, W., Lange, H., Jedicke, E. \& Reinke M. (Eds.) (2016). Landschaftsplanung. Berlin, Heidelberg: SpringerSpektrum. 
Ring, I., Hansjürgens, B., Elmqvist, T., Wittmer, H. \& Sukhdev P. (2010). Challenges in framing the economics of ecosystems and biodiversity: the TEEB initiative. Current Opinion of Environmental Sustainability, 2(1-2), 15-26. DOI: 10.1016/j.cosust.2010.03.005.

Ring, I. \& Schröter-Schlaack C. (Eds.) (2011). Instrument mixes for biodiversity policies. POLICYMIX Report, No. 2/2011. Leipzig: Helmholtz Centre for Environmental Research - UFZ. http://policymix.nina.no

Schlüter, H. (1982). Geobotanische Kennzeichnung und vegetationsökologische Bewertung von Naturraumeinheiten. Archiv für Naturschutz und Landschaftforschung, 22, 69-77.

Schutzgebiete Dresden (2018). Schutzgebiete in Dresden. http://www.dresden.de/de/stadtraum/umwelt/umwelt/ naturschutz/Schutzgebiete_nach_Naturschutzrecht.php

Schweppe-Kraft, B. (2009). Natural capital in Germany - State and valuation; with special reference to biodiversity. In R. Döring (Ed.), Sustainability, natural capital and nature conservation (pp. 193-216). Beiträge zur Theorie und Praxis starker Nachhaltigkeit, Vol. 3. Marburg: Metropolis.

Seják, J., Dejmal, I., Petř́iček, V., Cudlín, P., Míchal, I., Černý, K., Kučera, T., Vyskot, I., Strejček, J., Cudlínová, E., Cabrnoch, J., Šindlar, M., Prokopová, M., Kovář, J., Kupka, M., Sčasný, M., Šafařík, M., Roušarová, Š., Stejskal, V. \& Zapletal J. (2003). Monetary valuation of the habitats of the Czech Republic. Prague: Czech Ecological Institute, Ministry of Life Environment of the Czech Republic.

Seják, J. \& Cudlín P. (2010). On measuring the natural and environmental resource value and damages. Studia Ecologica, 4(2), 53-68.

Spangenberg, J.H. \& Settele J. (2010). Precisely incorrect? Monetising the value of ecosystem services. Ecological Complexity, 7(3), 327-337. DOI: 10.1016/j.ecocom.2010.04.007.

TEEB (2010). The economics of ecosystems and biodiversity. London: Earthscan.

TEEB (2011). TEEB manual for cities: Ecosystem services in urban management. London: Earthscan.

Tüxen, R. (1956). Die heutige potentielle natürliche Vegetation als Gegenstand der Vegetationskartierung. Angewandte Pflanzensoziologie, 13, 5-42.

UNEP (1992). The United Nations Convention on Biological Diversity.

User's Manual for CBI (2012): http://www.cbd.int/authorities/doc/User\%27s\%20Manual-for-the-City-BiodiversityIndex18April2012.pdf.

Werner, P. \& Zahner R. (2009). Biological diversity and cities. A review and bibliography. BfN-Skripten, 245.

Werner, P. (2016). Biologische Vielfalt im urbanen Raum. Zusammenhang, Entwicklung und Einflussfaktoren auf Flora und Fauna. Natur und Landschaft, 91(7), 314-321. DOI: 10.17433/7.2016.50153400. 